\title{
Competition Policy for Modern Banks
}

\author{
Lev Ratnovski
}




\title{
IMF Working Paper
}

\author{
Research Department
}

\section{Competition Policy for Modern Banks ${ }^{1}$}

\section{Prepared by Lev Ratnovski}

Authorized for distribution by Stijn Claessens

May 2013

\section{This Working Paper should not be reported as representing the views of the IMF.} The views expressed in this Working Paper are those of the author(s) and do not necessarily represent those of the IMF or IMF policy. Working Papers describe research in progress by the author(s) and are published to elicit comments and to further debate.

\begin{abstract}
Traditional bank competition policy seeks to balance efficiency with incentives to take risk. The main tools are rules guiding entry/exit and consolidation of banks. This paper seeks to refine this view in light of recent changes to financial services provision. Modern banking is largely market-based and contestable. Consequently, banks in advanced economies today have structurally low charter values and high incentives to take risk. In such an environment, traditional policies that seek to affect the degree of competition by focusing on market structure (i.e. concentration) may have limited effect. We argue that bank competition policy should be reoriented to deal with the too-big-to-fail (TBTF) problem. It should also focus on the permissible scope of activities rather than on market structure of banks. And following a crisis, competition policy should facilitate resolution by temporarily allowing higher concentration and government control of banks.
\end{abstract}

JEL Classification Numbers: G20, G24, G28

Keywords: Banks, Competition Policy, Macroprudential Policy, Systemic Risk. Author's E-Mail Address: LRatnovski@imf.org.

\footnotetext{
${ }^{1}$ I thank Elsie Addo Awadzi, Atilla Arda, Valerie Cerra, Jack Chen, Stijn Claessens, Francesco Columba, Olivier De Jonghe, Enrica Detragiache, Giovanni Dell'Ariccia, Johannes Ehrentraud, Laura Kodres, Luc Laeven, Matej Marinč, Aditya Narain, Erlend Nier, and Nico Valckx for helpful comments, and Lindsay Mollineaux for excellent research assistance.
} 


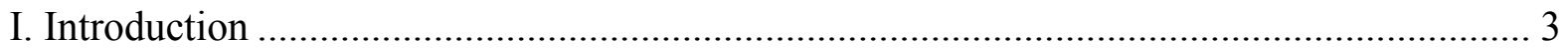

II. The Traditional Approach: "Structure - Competition - Risks" .................................... 4

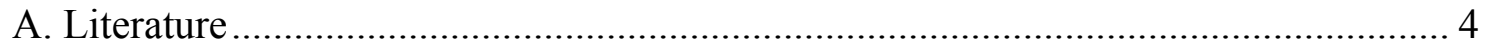

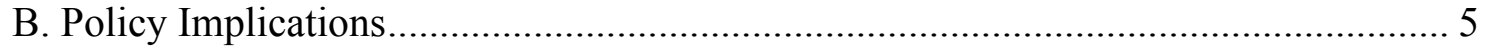

III. Modern View: Market-based and Contestable Banking ............................................. 6

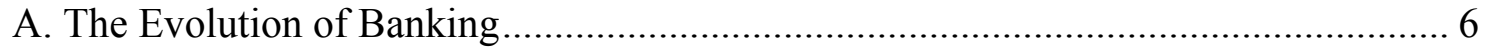

B. Implications for Competition and Prudential Policies ........................................... 8

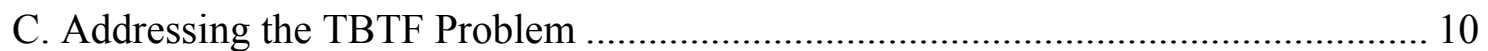

D. Interaction with Structural Policies....................................................................... 12

E. Competition Policy and Crisis Management .......................................................... 13

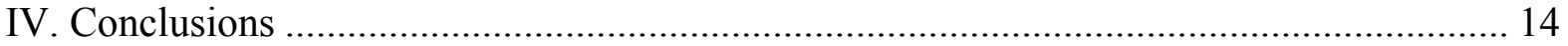

Figure

1. Evolution of Bank Business Model: Information, Profits, Scalability ….......................... 7

2. Bank Concentration and Performance during the 2008 Crisis......................................... 8

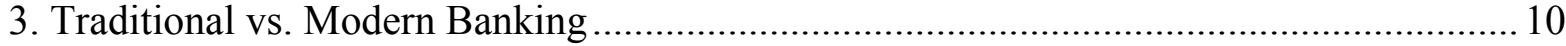

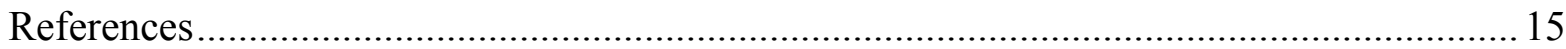




\section{INTRODUCTION}

Bank competition policy has been a focus of much research and policy debate. The reason for this is the special nature of banks. In the non-financial sector, competition policy mainly focuses on efficiency (competitive pricing). ${ }^{2}$ Yet for banks and the financial sector more generally there is another relevant dimension: systemic risk. As the recent crisis showed, excessive risk-taking by banks has significant welfare implications since there are large negative externalities of bank distress for the real economy. When the degree of competition adversely affects banks' risk-taking incentives, this should be internalized by competition policy. Put differently, bank competition policy should have a macro-prudential component.

The paper consists of two parts. We start, in Section II, by describing the "traditional" approach to competition policy for banks. It suggests that competition may impact bank stability in a non-linear manner: much competition reduces bank charter values and may increase incentives to take risk, while little competition leads to inefficiencies and may add to the too-big-to-fail (TBTF) problem. As a consequence, an intermediate level of competition is optimal. This level can be achieved through policies on (foreign) entry and exit, and actions regarding the consolidation of banks.

We proceed, in Section III, to emphasize some fundamental changes to the structure of banking over the last two decades, notably in advanced economies. Financial innovation has expanded access to hard (quantifiable, non-proprietary) information on borrowers, making banking less information-intensive and relationships-oriented, and more contestable and market-based. Contestability implies that charter values of banks are structurally low, while the traditional competition policy that focuses on concentration has weak if any effects on bank incentives. We argue that, consequently, the emphasis of bank competition policy in advanced economies should shift. It should $(i)$ reorient itself towards dealing with the TBTF problem, (ii) focus on scope (range of activities of banks and non-banks) rather than the market structure (concentration) of banks, and (iii) following a crisis allow higher concentration and government control of banks to facilitate crisis resolution even when that temporary distorts competition.

\footnotetext{
${ }^{2}$ There are additional considerations for dynamic gains - incentives to make fixed investments and/or innovate.
} 


\section{The Traditional APProach: "STructure - COMPeTITION - Risks"}

\section{A. Literature}

The theoretical predictions and empirical results on the link between bank competition, risktaking, and stability are somewhat ambiguous. But on net they suggest that an intermediate degree of bank competition is optimal, i.e. no excess restrictions but no unbridled competition either. ${ }^{3}$

Much of theoretical literature warns that competition may increase bank risk-taking. Competition lowers margins and charter value (the discounted stream of profits) of banks, making them more willing to gamble and less able to withstand negative shocks (Marcus, 1984; Chan et al., 1986; Keeley, 1990; Hellman et al., 2000; Matutes and Vives, 2000; Repullo, 2004). Another channel is that competition may force banks to focus on maintaining market share instead of screening existing borrowers (Dell'Ariccia and Marquez, 2006).

Yet some papers highlight opposite effects where bank competition lowers interest rates in the economy, making borrowers safer and reducing risk (Boyd and De Nicolo, 2005). The effects can be reconciled in models that show an inverse U-shaped relationship between bank competition and stability. There, introducing competition in monopolistic systems initially increases stability as borrowers become safer, but high competition becomes destabilizing due to the charter value effect (Martinez-Miera and Repullo, 2010).

Empirical literature also offers ample evidence that too much bank competition may reduce stability. (In the papers, competition is measured through margins or concentration, and stability is captured as loan quality or probability of failure; see Keeley, 1990; Dick, 2006; Jimemez et al., 2007; Boyd and Runkle, 1993; Beck et al., 2006a,b.) There is evidence that competition distorted credit quality also during the recent crisis (Dell'Ariccia, et al., 2012). Interestingly, some papers show that the stability effects of lower competition stem not from charter values, but from diversification benefits in large banks (Paroush, 1995; Benston et al., 1995; Craig and Santos, 1997; Beck et al., 2006a,b).

Yet as theory predicts, too little competition may compromise bank stability. This is predominantly driven by distortions in large banks. As banks get larger and more diversified, they may increase the risks of their portfolios, or strategically choose to operate at a closer distance to default (Chong, 1991; Hughes and Mester, 1998; De Nicolo, 2000; Boyd et al., 2006). Larger banks also become subject to internal inefficiencies and increased operational

\footnotetext{
${ }^{3}$ We offer a concise survey of the literature; for extensive surveys see Allen and Gale, 2004; Beck, 2008; Claessens, 2009.
} 
risk (Beck et al., 2006; Laeven and Levine, 2007; Cetorelli et al., 2007). ${ }^{4}$ Taken together, the two effects may - similar to the theoretical predictions - lead to an inverse U-shaped effect of bank competition on stability, as suggested in recent papers (Fernandez and Maudos, 2011; Calbo-Valverde et al., 2013).

Of course, beyond the ambiguous effect of risk, higher competition is beneficial - in the static sense - as it lowers costs and increases access to finance, benefitting most firms (especially financially dependent ones, see Petersen and Rajan, 1995) and households. But there are two caveats. First, competition may make banking services more arm's length and hence disadvantage information-sensitive borrowers (Berger et al., 2004; Carow et al., 2004; Karceski et al., 2005; Sapienza, 2002; Degryse et al., 2005). Second, when banks do not have good knowledge of customers, they may restrict credit during downturns (Petersen and Rajan, 1994; Bae et al., 2002; Bolton at al., 2012), increasing procyclicality.

\section{B. Policy Implications}

The literature therefore suggests that an intermediate degree of bank competition is optimal. Competition should not be unbridled in order to allow banks to accumulate charter value that offsets their risk-taking incentives. But too little competition may make banks inefficient and possibly also lead to the TBTF problem.

The intermediate level of bank competition may be achieved by policies that focus on market structure (i.e. concentration):

- Entry/exit rules (for domestic and foreign banks);

- Consolidation policy (which may be particularly relevant around crises, when authorities can direct bank mergers; see Perotti and Suarez, 2003);

- Restrictions on activities (non-lending activities of banks, and bank-like activities of nonbanks such as insurance companies).

And by policies that affect contestability in banking services (competition given market structure):

- Establishing credit registries;

- Providing equal access to infrastructure, such as payment systems;

- Other measures that enable easier switching of banks by customers.

\footnotetext{
${ }^{4}$ An additional caveat is that when a concentrated system arises as a result of significant restrictions on entry, this may be a sign of an overall weak regulatory framework, and hence an instable system (Jayaratne and Strahan, 1998; Barth et al., 2004; Beck et al., 2006 a,b).
} 


\section{Modern View: MARKet-Based ANd Contestable BANKIng}

\section{A. The Evolution of Banking}

The last two decades saw some fundamental shifts in the nature of financial services provision in advanced economies. Progress in information technology increased the availability of "hard" (quantifiable, verifiable) information on borrowers. This reduced the grip that banks had over their customers thanks to "soft" (proprietary) information accumulated in existing bank-customer relationships. ${ }^{5}$ Banking became more contestable, with lower profits and reduced charter values. And hard information made bank operations scalable, as banks could more easily access new customers.

In addition, hard information increased the tradability of bank assets. Banks can now use markets to acquire or dispose of assets (e.g. of securitized debt) and engage in transactions (e.g. proprietary trading). Market-based operations of banks are particularly contestable, with low per unit profits, but easily scalable (Boot and Ratnovski, 2012).

To be clear, some parts of the banking business, such as SME and syndicated lending, as well as much of lending in less advanced economies, are still intensive in soft information. However, overall, hard information plays an increasingly important role. A modern bank combines businesses based on hard and soft information.

The following figures for U.S. banks illustrate the evolution of banking from the 1990-s to 2007 (Liikanen et al., 2012, suggest similar trends in Europe):

- The net interest margin on lending fell from $4 \%$ to $3.25 \%$;

- The share of trading assets and securities in total assets increased from $20 \%$ to $30 \%$, and the share of non-interest income in revenue increased from 35\% to 50\% (NY Fed, 2012);

- The average return on trading assets, $2 \%$, was significantly below the $6 \%$ return on lending (derived as the net interest margin plus the $3 \%$ average cost of funding; FHLB $\mathrm{SF}, 2012){ }^{6}$

\footnotetext{
${ }^{5}$ For example, under soft information, borrowers might have had troubles proving their creditworthiness to anyone except for the one bank that had detailed knowledge about them thanks to pre-existing long-lasting relationship. With hard information, borrowers can approach other banks and prove their creditworthiness using techniques such as credit scoring. Thus, hard information reduces the capture of customers by banks and enables easier bank switching ("shopping around" for loans and other financial services).

${ }^{6}$ Part of the change in net interest margins can be attributed to cyclical factors (IMF, 2012). The measures of trading assets and non-interest income are proxies for the importance of hard information. In practice, some loans may also be based on hard information, while some (fees) may stem from soft information-based relationship lending. The overall trend is nevertheless unambiguous. The trend continues post 2007, but direct comparisons of pre- and post-crisis numbers are imprecise because the underlying sample was expanded by
} 
Figure 1. Evolution of Bank Business Model: Information, Profits, Scalability

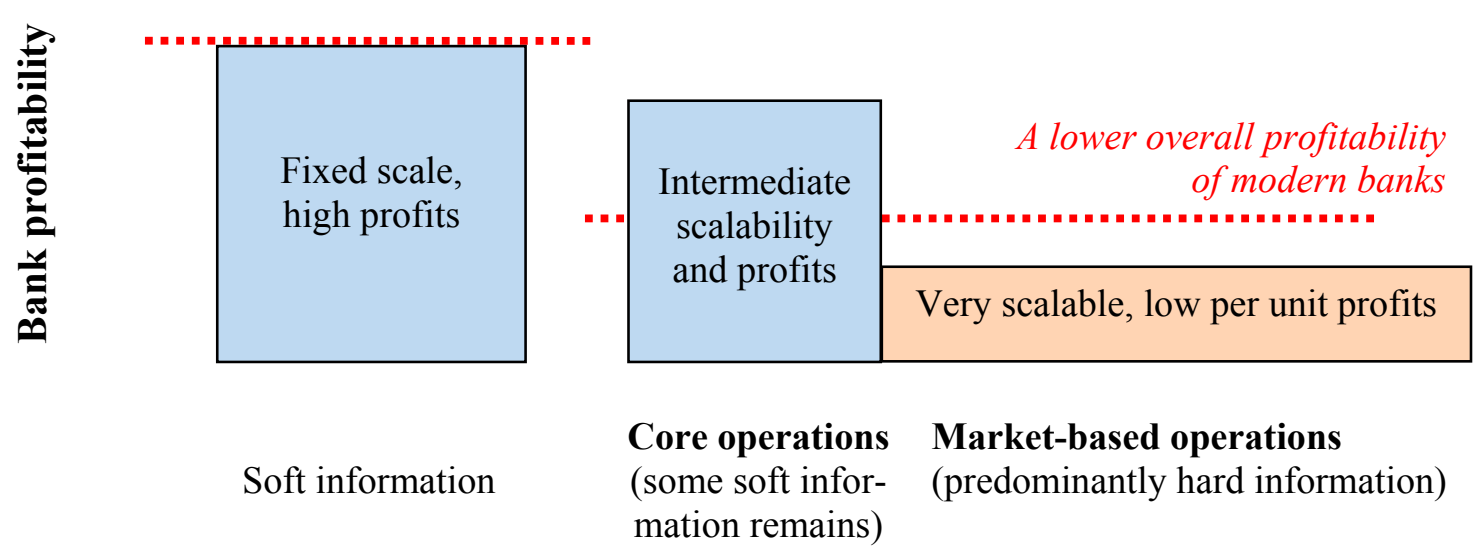

Traditional banks

Modern banks

\section{Bank scale}

Figure 1 illustrates the recent changes: lower profits in the traditional core operations of banks due to increased competition, and even lower (per unit) profits and high scale in market-based activities. ${ }^{7}$

The effects of increased hard information on contestability in banking are further amplified through several channels. First, hard information facilitates cross-border expansion of banks (as banks need less local knowledge to enter distant markets), thus increasing bank competition. Second, debt claims based on hard information can serve as collateral in obtaining wholesale funds (in repos, securitization, and covered bonds); this better access to funding again intensifies bank competition (Dell'Ariccia and Marquez, 2006). Finally, hard information enables an "originate-to-distribute" business model, under which non-banks (e.g. finance companies that do not have own depositor base) can more easily enter lending markets and compete with banks.

including former standalone investment banks that were given bank licenses or merged into bank holding companies.

${ }^{7}$ Note that, in practice, the boundary between core, non-core, and market-based activities of banks is blurred: bank operations can have different degrees of soft/hard information and marketability. For marketability, sometimes banks may make marketable only the tranches (cash-flows) that are linked to hard information and retain tranches (cash flows) over the risk of which they have soft information (as in securitization; see Claessens et al., 2012). 


\section{B. Implications for Competition and Prudential Policies}

The shift to modern banking creates prudential challenges. When banking is more contestable, with lower margins and charter values per unit of exposure, banks have higher incentives to take risk. At the same time, banks can grow aggressively in size, because hard information allows them to expand beyond the established customer base. And banks can use market-based activities to take large-scale, opportunistic gambles. ${ }^{8}$ So banks have both incentives and a high ability to take risks on a large scale. These prudential challenges imply need for a stronger prudential component in competition policy.

At the same time, traditional competition policy that focuses on bank market structure (entry/exit and consolidation of banks) to maintain charter values and restrict risk-taking of banks becomes less effective. The reason is that, due to contestability, charter values (and incentives to take risk) respond less to changes in market structure. The fact that the link between market structure and competition on the one hand, and risk-taking on the other hand is weak has been long recognized in the literature (Claessens and Laeven, 2004; DemirgucKunt et al., 2004), but insufficiently reflected so far in policy debates.

\section{Figure 2. Bank Concentration and Performance during the 2008 Crisis}

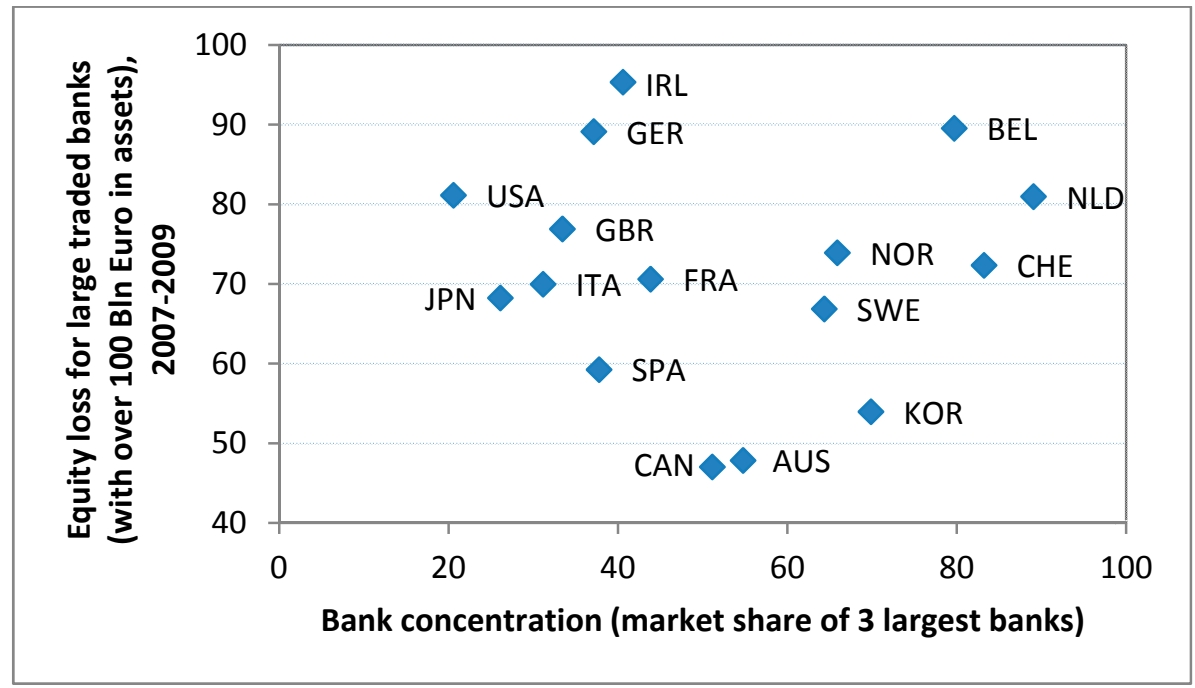

Source: World Bank Financial Structure Database (Beck and Demirguc-Kunt, 2009) and author's calculations (Huang and Ratnovski, 2009).

\footnotetext{
${ }^{8}$ A common type of such risk-taking in the run-up the crisis was for banks to take leveraged positions in highgrade securitized debt. These positions offer a positive return in most states of the world (benefitting shareholders and managers), but lead to extreme losses with a low probability (which has realized during the crisis; the losses fell on the creditors and governments during bailouts, see Acharya et al., 2010).
} 
Figure 2 illustrates the fact that the relationship between market structure - measured as concentration - and the performance of banking system during the financial crisis was weak. While one could see in the scatter plot some inverse U-shaped relationship predicted by the standard arguments (driven by positions of Canada and Australia - the countries least affected by the crisis), in fact such relationship would have limited economic or policy significance, as banks from countries with similar bank concentration were vastly differently affected by the crisis (compare Canada, France, and Ireland). Other factors - notably noncore exposures funded in wholesale markets (e.g. in Germany and UK) along with high leverage (e.g. in Ireland or Germany) - have certainly played a larger role in explaining bank performance. ${ }^{9}$

The new prudential challenges raised by the more market-based nature of financial intermediation and the lower effectiveness of existing policy tools imply a need for a fundamental re-evaluation of the objectives and tools of bank competition policy. Traditional tools described in Section II.B remain relevant to the extent that banking continues to rely on some soft information. But the increasing presence of hard information-based financial services calls for new priorities and methods in how competition policy could enhance the stability of modern banks. Specifically, it raises three new policy and research areas for bank competition policy:

1. Addressing the TBTF problem. The ability of modern banks to easily increase scale leads to a more acute TBTF problem. ${ }^{10}$ Competition policy tools might need to be used to restrict the size of large banks. Competition policy should also deal with the distortions created by TBTF: an uneven playing field that arises because of cheaper funding available to TBTF banks.

2. Understanding the interactions with structural issues. Much of excess risk-taking in modern banks occurs for structural reasons: banks may take too much risk in market-based operations; another source of distortions is competition from non-banks. Competition policy has interactions with and may complement recent structural bank regulation initiatives.

3. Facilitating crisis management. Effective resolution of financial crises might require measures that temporary distort competition, such as government ownership and control of banks, or high bank concentration. Competition policy may need to accommodate these to facilitate effective bank resolution.

\footnotetext{
${ }^{9}$ Moreover, even if a relationship between concentration and stability was present, the optimal concentration would be subject to significant cross-country heterogeneity (it depends on financial development, quality and stringency of regulation, etc., cf. Beck et al., 2013). This makes it hard to use a certain degree of bank concentration as a universal policy objective; any prescriptions have to be country specific.

${ }^{10}$ Normally, exit from contestable industry has a low (social) cost. But banks failures (a type of exit) may lead to contagion and disrupt the industry as a whole. I.e. TBTF banks can pose systemic risk despite contestability.
} 
Figure 3. Traditional vs. Modern Banking

\begin{tabular}{|c|c|c|c|}
\hline & \multirow[b]{2}{*}{ Traditional banks } & \multicolumn{2}{|c|}{ Modern banks } \\
\hline & & $\begin{array}{c}\text { Core } \\
\text { operations }\end{array}$ & $\begin{array}{c}\text { Market-based } \\
\text { operations }\end{array}$ \\
\hline \multicolumn{4}{|c|}{ Fundamentals } \\
\hline Type of information & Soft (proprietary) & Some soft & Hard (quantifiable) \\
\hline Contestability & Low & Intermediate & High \\
\hline Scalability & Low & Intermediate & High \\
\hline \multicolumn{4}{|c|}{ Bank conduct } \\
\hline Charter value & High & Intermediate & Low \\
\hline Incentives to take risk & Low & Intermediate & High \\
\hline Ability to generate risk & Low & Intermediate & High \\
\hline \multicolumn{4}{|c|}{ Implications for competition policy } \\
\hline Prudential risks & Relatively low & \multicolumn{2}{|c|}{ High } \\
\hline $\begin{array}{l}\text { Effectiveness of traditional compe- } \\
\text { tition policy (focused on concen- } \\
\text { tration) in reducing bank risk-taking }\end{array}$ & High & \multicolumn{2}{|c|}{ Limited } \\
\hline TBTF problem & $\begin{array}{l}\text { Limited (hard to operate } \\
\text { on a large scale under soft } \\
\text { information) }\end{array}$ & \multicolumn{2}{|c|}{$\begin{array}{l}\text { Acute; competition policy can (a) reduce } \\
\text { TBTF and (b) deal with the competitive } \\
\text { distortions of TBTF }\end{array}$} \\
\hline Structural concerns & $\begin{array}{l}\text { Limited } \\
\text { (simple structure) }\end{array}$ & \multicolumn{2}{|c|}{$\begin{array}{l}\text { Present; competition policy may improve } \\
\text { stability by using restrictions on activities } \\
\text { of banks and non-banks }\end{array}$} \\
\hline Bank resolution & $\begin{array}{l}\text { Can be relatively simple } \\
\text { (FDIC style) }\end{array}$ & \multicolumn{2}{|c|}{$\begin{array}{l}\text { Complex; competition policy might need } \\
\text { to accommodate a range of crisis } \\
\text { management tools }\end{array}$} \\
\hline
\end{tabular}

Figure 3 summarizes the discussion so far. Next, we discuss these three priorities in more detail.

\section{Addressing the TBTF Problem}

The literature has long recognized the dangers of "too-big-to-fail" (TBTF) banks. Such banks are complex and interconnected, and cannot be easily wound down. Historically, most interventions in TBTF banks were de facto bailouts, which protected their creditors (and sometimes shareholders too) from full distress-related losses. The anticipation of bailouts increases the incentives of TBTF banks to take risk, and introduces a race among banks to become TBTF, in order to have a lower cost of funding due to the protection against losses (O’Hara and Shaw, 1990; Flannery, 2009; Ueda and Weder di Mauro, 2012). 
In modern banking, the TBTF problem is especially acute for a number of reasons:

- There are little public or market pressures to deal with large banks. A modern banking system can be competitive despite being concentrated, thanks to contestability. Outside of financial crises, banks are not extracting surplus from savers and borrowers, so there is little pressure to shrink them. And during crises, authorities may excessively use bank mergers (instead of standalone resolution) for crisis management, as they are not constrained by negative competitive effects.

- Banks have incentives to grow. This is the way to maximize the TBTF subsidy, benefit from possible economies of scale in market-based activities, and from business opportunities driven by "network centrality" (for example, when a well-connected bank can run a more profitable dealer operation, see Claessens et al., 2012).

- It is easy for banks to grow. Activities based on hard information, especially marketbased ones, are scalable. And, hard information enables larger organizations (Stein, 2002).

Thus, modern banking creates conditions for the TBTF problem to "creep in." The TBTF problem is well recognized as a major prudential concern. Currently, policy aims to address it through Basel III capital surcharges for systemically important banks (SIFIs). Yet there are concerns that this may be insufficient to fully deal with the TBTF problem (see Haldane, 2012 and 2013). The main reason is that the Basel SIFI capital surcharge is relatively small (up to 2.5 percent of risk-weighted assets). The cost of extra capital may be offset by the benefits of cheaper funding associated with being TBTF. Then the surcharge may not give banks sufficient incentives to shrink or cut risks. There is therefore both a need and much scope to use in addition competition policy to address the TBTF problem. There are two approaches by which this can be done, a quantity- and a price-based approach.

The quantity-based approach is to use competition policy tools to directly restrict bank size. This can be achieved by limiting mergers, forcing spin-offs, etc. The challenge for this approach is to find a correct rationale for using such tools. Modern banks can act competitively and be efficient despite their size. Moreover, large banks may demonstrate spurious economies of scale, i.e., seem more efficient than small ones, thanks to: (a) lower cost of funds due to the TBTF subsidy, (b) less borrower screening because they can afford more risk in lending operations, and (c) more market-based activities, which are scalable but risky. It may therefore be hard to restrict bank size on pure competitive grounds. There are two ways around this. One way is to let competition policy adopt an explicit macroprudential objective, which would enable it to deal with large banks on the grounds of the welfare costs of possible crises. Another way, maybe more easily acceptable, is to focus on subsegments of bank operations where bank size may indeed be a detriment to competition. For example, large banks are generally poor in dealing with opaque customers, such as small 
business borrowers or other customers intensive in "local" information. Ensuring access to finance on competitive terms by such customers may offer a rationale to restrict bank size or facilitate bank entry on pure competitive grounds.

The price-based approach is to use competition policy to correct competitive distortions created by TBTF. Interestingly, this may reduce the underlying TBTF problem as well. A key distortion is the uneven playing field that arises because large banks have access to cheaper funding than small banks. The cheaper funding is a result of an implicit TBTF guarantee to large banks' creditors (that they will be bailed out in a crisis); the size of the funding advantage can be as high as 80 basis points a year (Ueda and Weder di Mauro, 2012). This distortion affects static competition, is a barrier to entry, and creates socially inefficient incentives for banks to grow. Correcting the uneven playing field is a natural goal for competition policy. The most direct tool to do so is to impose taxes or fines on large banks, to extract their unfair competitive advantage. (Think of a tax on wholesale funding of banks, with a rate that is increasing in bank size.) From the perspective of competition policy, this would ensure a level playing field. From the prudential perspective, such taxes or fines would reduce the excess incentives of banks to grow, reducing the TBTF problem and enhancing financial stability.

\section{Interaction with Structural Policies}

The complexity of today's financial system creates scope for structural policies. Structural policies, as defined here, are prudential measures that restrict bank or non-bank activities that contribute to systemic risk (Haldane, 2012; Gambacorta and van Rixtel, 2013). The recent crisis highlighted that systemic risk may indeed by driven by specific activities of financial intermediaries. Many bank failures were a consequence of non-core, market-based bank activities: investing in securitized credit, wholesale loan origination ("originate-todistribute"), carry trade, proprietary trading (see Acharya et al., 2010; Boot and Ratnovski, 2012). At the same time, at the aggregate level, bubbles in housing markets were amplified by the lending of under-regulated non-banks (Dagher and Fu, 2012). Recent structural policy initiatives - which aim to reduce the risks described above - affect the competitive environment, and therefore have important interactions with competition policy.

A number of recent proposals suggest restricting market-based activities of banks:

prohibition of proprietary trading in the Volcker Rule in the Dodd-Frank Act in the U.S. or a segregation of a wide range of non-core activities in the Vickers and Liikanen proposals in UK and for EC. Non-core activities are risky and have low margins, so restricting them might boost charter value and increase the stability of banks. (To some extent, these proposals entail moving banks closer to a traditional, soft information-intensive bank business model.) Restrictions on bank activities may ease competition policy. By separating less contestable (core) from more contestable (non-core, including international) activities, it 
would allow competition policy to be more targeted: that is, able to use different approaches to the two sub-sectors, instead of focusing on banking as a whole. ${ }^{11}$ For the core bank activities, it may mean more clarity on the competitive environment, and more precise competition policy.

Another possible structural measure is restricting competition in lending from non-banks. While historically lending was largely a bank-based activity, hard information allows nonbanks, such as finance companies or independent mortgage originators, to compete directly with banks. In the run-up to the crisis, lending by non-banks was riskier than that by banks (Dagher and Fu, 2012; Demyanyuk and Loutskina, 2012). This likely put pressures on banks to follow suit in order to maintain market share. Overall, non-bank lending amplified the mortgage bubble and led to riskier bank balance sheets. Non-bank lending was riskier in part because non-banks faced lax regulatory standards. Besides leading to more risk, the lax regulatory standards gave non-banks an artificial competitive advantage (of being less constrained by capital requirements or other prudential rules). Competition policy may help prudential policy by insisting on level playing field in lending, where non-banks can only compete directly with banks if they are subject to the same or similar prudential standards.

The third structural problem highlighted by the crisis is excess competition for retail deposits. Retail deposits are scarce (their supply is capped by the part of household saving that goes to banks), yet valuable to banks because insured deposits are the most stable source of funds (Huang and Ratnovski, 2009 and 2011). There were various types of excess competition for deposits in the run-up to the crisis. One was competition from non-banks (such as insurance companies, asset managers, money market funds) for household savings - as in Australia or the Nordics. Another was competition from local savings banks with implicit public guarantees that historically accumulated a large share of depositor base - notably in Germany. In any case, commercial banks were left with too little household deposits and had to rely on wholesale funding, which was a major source of vulnerability during the crisis. Resolving the scarcity of deposits is a key structural challenge for policy. Competition policy might assist by establishing a level playing field in access to household savings - including by dealing with implicit guarantees and lax regulation of non-banks.

\section{E. Competition Policy and Crisis Management}

The crisis put into sharp relief possible conflicts between bank competition policy and crisis management (Vickers, 2010; Hasan and Marinč, 2013). Normally, competition policy advocates limited government involvement in banks in order to maintain the level playing

\footnotetext{
${ }^{11}$ This is similar in spirit to having distinct competition policies for, say, providers of communication network infrastructure and producers of communication equipment.
} 
field between government-affiliated and other banks. Yet, crisis management might exceptionally require governments to take ownership in banks or offer banks guarantees in order to maintain financial stability and the capacity to lend. Also, governments might need to exercise control over banks to direct their restructuring. (These measures are not the only or most efficient paths for crisis management, but may be necessary under some conditions; Laeven and Valencia, 2011.) In such exceptional circumstances, competition policy should acknowledge the trade-off between the need for effective bank resolution versus preserving the level playing field, and aim to strike a balance. Also, competition policy might need to temporarily allow higher banking system concentration, when that is necessary to allow banks to rebuild charter values or to facilitate the shrinking of a previously over-expanded banking system.

\section{Conclusions}

The analysis of this paper offers two main lessons. The first lesson is that because the degree of competition affects bank risk-taking, bank competition policy should have a macroprudential component. Sometimes there is a need to sacrifice some competition to ensure more financial stability. Therefore, bank competition policy may require rules that are distinct from those for non-financial firms. (This is similar to bank resolution laws that have different procedures than those in regular bankruptcy codes; Marinc and Vlahu; 2012.) In dealing with banks, the competition authority needs to cooperate closely with the prudential regulator. ${ }^{12}$

The second lesson is that bank competition policy should respond to the recent evolution of the banking industry and the new prudential challenges that it poses. While the key conclusion from existing literature - that an intermediate degree of competition in banking is optimal - remains valid, the way in which policy can achieve such optimal degree of competition has changed. In market-based, contestable banking, traditional policies that focus on market structure (i.e. concentration, through rules on entry/exit and consolidation) of banks have limited effect. Instead, competition policy should reorient itself on dealing with the TBTF problem, focus on scope of bank activities rather than simple concentration, and facilitate effective crisis resolution.

\footnotetext{
${ }^{12}$ This may not come easily, as the two authorities traditionally differ in objectives approaches, regulatory perimeter, etc.
} 


\section{REFERENCES}

Acharya, V.V., T.F. Cooley, M.P. Richardson, and I. Walter, 2010, "Manufacturing Tail Risk: A Perspective on the Financial Crisis of 2007-09," Foundations and Trends in Finance, 4.

Allen, F., and D. Gale, 2004, "Competition and financial stability," Journal of Money, Credit, and Banking, Vol. 36, No. 3, Pt.2, pp. 433-80.

Bae, H.-K., J.-K. Kang, and C.-W. Lim, 2002, “The Value of Durable Bank Relationships: Evidence from Korean Banking Shocks," Journal of Financial Economics, Vol. 64, pp. 181-214.

Barth, J.R., Caprio, Jr., G., and Levine, R., 2004, "Bank Supervision and Regulation: What Works Best?” Journal of Financial Intermediation, Vol. 13, No. 2, pp. 205-48.

Beck, T., and A. Demirgüç-Kunt, 2009, "Financial Institutions and Markets Across Countries and over Time: Data and Analysis," World Bank Policy Research Working Paper 4943.

Beck, T., 2008, "Bank Competition and Financial Stability: Friends or Foes,” World Bank Policy Research Working Paper 4656.

Beck, T., Demirgüç-Kunt, A., and Levine, R. (2006a) "Bank Concentration, Competition, and Crises: First Results,” Journal of Banking and Finance, 30, pp. 1581-603.

__, 2006b, "Bank Concentration and Fragility: Impact and Mechanics," in Stulz, R., and Carey, M. (eds), The Risks of Financial Institutions. National Bureau of Economic Research.

Beck, T., O. De Jonghe, and G. Schepens, 2013, “'Bank Competition and Stability: Crosscountry Heterogeneity," Journal of Financial Intermediation, forthcoming.

Benston, G., W.C. Hunter, L. Wall, 1995, “Motivations for Bank Mergers and Acquisitions: Enhancing the Deposit Insurance Put Option Versus Earnings Diversification," Journal of Money, Credit and Banking, Vol. 27, pp. 777-88.

Berger, A., Demirgüç-Kunt, A., Haubrich, J., and Levine, R., 2004, "Bank Concentration and Competition: An Evolution in the Making," Journal of Money, Credit, and Banking, Vol. 36, pp. 433-53.

Bolton, P., X. Freixas, L. Gambacorta, and P.E. Mistrulli, 2012, "Relationship and Transaction Lending in a Crisis," Working Paper.

Boot, A.W.A., and L. Ratnovski, 2012, "Banking and Trading," IMF Working Paper 12/238.

Boyd, J.H., and D. Runkle, 1993, “Size and Performance of Banking Firms,” Journal of Monetary Economics, Vol. 31, pp. 47-67.

Boyd, J.H., and G. De Nicoló, 2005, "The Theory of Bank Risk-Taking and Competition Revisited," Journal of Finance, Vol. 60, pp. 1329-343. 
Boyd, J.H., G. De Nicoló, and A. Jalal, 2006, "Bank Risk Taking and Competition: New Theory, New Empirics," IMF Working Paper 06/297.

Calbo-Valverde, S., L.E. Pedauga, and F. Rodriguez-Fernandez, 2013, “Another Look at Bank Consolidation and Financial Stability,” Working Paper.

Carow, K.A., Edward Kane, and R. Narayanan, 2004, "How Have Borrowers Fared in Banking Mega-Mergers?" Working Paper.

Cetorelli, N., B. Hirtle, D. Morgan, S. Peristiani, J. Santos, 2007, "Trends in Financial Market Concentration and Their Implications for Market Stability," Economic Policy Review, Federal Reserve Bank of New York, issue Mar.

Chan, Y.-S., S. Greenbaum, and A. Thakor, 1986, "Information Reusability, Competition and Bank Asset Quality," Journal of Banking and Finance, Vol. 10, 243-53.

Chong, B.S., 1991, "Effects of Interstate Banking on Commercial Banks' Risk and Profitability," Review of Economics and Statistics, Vol. 73, pp. 78-84.

Claessens, S., 2009, "Competition in the Financial Sector: Overview of Competition Policies," IMF Working Paper 09/45. Also in: World Bank Research Observer, 2009, Vol. 24, No.1, pp. 83-118 (February).

Claessens, S., and L. Laeven, 2004, "What Drives Bank Competition? Some International Evidence," Journal of Money, Credit, and Banking, Vol. 36, No. 3, Pt.2, pp. 563-83.

Claessens, S., Z. Pozsar, L. Ratnovski, and M. Singh, 2012, "Shadow Banking: Economics and Policy," IMF Staff Discussion Note 12/12.

Craig, B., and J. Santos, 1997, "The Risk Effect of Bank Acquisitions," Federal Reserve Bank of Cleveland Economic Review Q II, pp. 25-35.

Dagher, J., and N. Fu, 2012, "What Fuels the Boom Drives the Bust: Regulation and the Mortgage Crisis," IMF Working Paper 11/215.

De Nicoló, G., 2000, "Size, Charter Value and Risk in Banking: An International Perspective," International Finance Discussion Paper \#689, Board of Governors of the Federal Reserve System.

Degryse, H., N. Masschelein, and J. Mitchell, 2005, "SMEs and Bank Lending Relationships: The Impact of Mergers," CEPR Working Paper No. 5061.

Dell'Ariccia, G., and R. Marquez, 2006, "Lending Booms and Lending Standards," Journal of Finance, Vol. 61, No. 5, pp. 2511-546.

Dell'Ariccia, G., D. Igan, and L. Laeven, 2012, "Credit Booms and Lending Standards: Evidence from the Subprime Mortgage Market," Journal of Money, Credit and Banking, Vol. 44, No. 2-3, pp. 367-84. 
Demirgüç-Kunt, A., L. Laeven, and R. Levine, 2004, "Regulations, Market Structure, Institutions, and the Cost of Financial Intermediation," Journal of Money, Credit, and Banking, Vol. 36, No. 3, Pt.2, pp. 593-622.

Demyanyuk, Y., and E. Loutskina, 2012, "Mortgage Companies and Regulatory Arbitrage," Working Paper.

Dick, A., 2006, "Nationwide Branching and Its Impact on Market Structure, Quality and Bank Performance," Journal of Business, Vol. 79, No. 2, pp. 567-92.

Fernandez, J., and J. Maudos, 2011; "Banking Competition and Economic Growth: CrossCountry Evidence," European Journal of Finance, Vol. 17, No. 8, pp. 739-64.

FHLB SF [Federal Home Loan Bank of San Francisco], 2012, The Cost of Funds Index.

Flannery, M.J., 1989, “Capital Regulation and Insured Banks' Choice of Individual Loan Default Risks," Journal of Monetary Economics, Vol. 24, pp. 235-58.

Gambacorta, L., and A. van Rixtel, 2013, "Structural Bank Regulation Initiatives: Approaches and Implications," BIS Working Paper 412.

International Monetary Fund, 2012, Global Financial Stability Report, Oct., Ch. 3.

Haldane, A., 2012, "On Being the Right Size," Speech given at Institute of Economic Affairs 22nd Annual Series, The 2012 Beesley Lectures at the Institute of Directors.

_, 2013 , “Have We Solved 'Too Big To Fail'?" VOXEU, available at: http://www.voxeu.org/article/have-we-solved-too-big-fail.

Hasan, I., and M. Marinč, 2013, "Should Competition Policy in Banking Be Amended during Crises? Lessons from the EU," Working Paper.

Hellman, T., K. Murdock, and J.E. Stiglitz, 2000, "Liberalization, Moral Hazard in Banking and Prudential Regulation: Are Capital Controls Enough?” American Economic Review, Vol. 90, No. 1, pp. 147-65.

Huang, R., and L. Ratnovski, 2009, “Why Are Canadian Banks More Resilient?” IMF Working Paper 09/152.

— 2011, “The Dark Side of Bank Wholesale Funding,” Journal of Financial Intermediation, Vol. 20, No. 2, pp. 248-63.

Hughes, J.P., and L. Mester, 1998, "Bank Capitalization and Cost: Evidence of Scale Economies in Risk Management and Signaling," Review of Economics and Statistics, Vol. 80, pp. 314-25.

Jayaratne, J., and P. Strahan, 1998, "Entry Restrictions, Industry Evolution, and Dynamic Efficiency: Evidence from Commercial Banking," Journal of Law and Economics, Vol. 41, pp. 239-75.

Jimenez, G., J. Lopez, and J. Saurina, 2007, “How Does Competition Impact Bank RiskTaking?” Federal Reserve Bank of San Francisco Working Paper 2007-23. 
Karceski, J., S. Ongena, and D.C. Smith, 2005, "The Impact of Bank Consolidation on Commercial Borrower Welfare," Journal of Finance, Vol. 60, pp. 2043-082.

Keeley, M.C., 1990, “Deposit Insurance, Risk and Market Power in Banking," American Economic Review, Vol. 80, pp. 1183-200.

Laeven, L., and F. Valencia, 2012, “Systemic Banking Crises Database: An Update," IMF Working Paper 12/163.

Laeven, Luc, and Ross Levine, 2007, "Is There a Diversification Discount in Financial Conglomerates?" Journal of Financial Economics, Vol. 85, No. 2, pp. 331-67

Liikanen, E. (Chair), 2012, High-level Expert Group on Reforming the Structure of the EU Banking Sector: Final Report.

Marcus, A.J., 1984, "Deregulation and Bank Financial Policy," Journal of Banking and Finance, Vol. 8, pp. 557-65.

Marinč, M., and R. Vlahu; 2011, The Economics of Bank Bankruptcy Law, Springer.

Martinez-Miera D., and R. Repullo, 2010, "Does Competition Reduce the Risk of Bank Failure?" Review of Financial Studies, Vol. 23, pp. 3638-664.

Matutes, C., and X.Vives, 2000, "Imperfect Competition, Risk Taking and Regulation in Banking," European Economic Review, Vol. 44, pp. 184-216.

NY Fed [Federal Reserve Bank of New York], 2012, Quarterly Trends for Consolidated U.S. Banking Organizations (Second Quarter).

O’Hara, M., and W. Shaw, 1990, "Deposit Insurance and Wealth Effects: The Value of Being 'Too Big to Fail,” Journal of Finance, Vol. 45, pp. 1587-600.

Paroush, J., 1995, "The Effect of Merger and Acquisition Activity on the Safety and Soundness of a Banking System," Review of Industrial Organization, Vol. 10, pp. 53-67.

Perotti, E., and J. Suarez, 2003, “Last Bank Standing: What Do I Gain if You Fail?” European Economic Review, Vol. 46, pp. 1599-622.

Petersen, M., and R. Rajan, 1995, "The Effect of Credit Market Competition on Lending Relationships," Quarterly Journal of Economics, Vol. 110, pp. 407-35.

— 1994 , "The Benefits of Lending Relationships: Evidence from Small Business Data," Journal of Finance, Vol. 49, No. 1, pp. 3-37.

Repullo, R., 2004, “Capital Requirement, Market Power, and Risk-Taking in Banking," Journal of Financial Intermediation, Vol. 13, pp. 156-82.

Sapienza, P., 2002, "The Effects of Banking Mergers on Loan Contracts," Journal of Finance, Vol. 57, pp. 1891-921.

Stein, J., 2002, "Information Production and Capital Allocation: Decentralized versus Hierarchical Firms," Journal of Finance, Vol. 57, No. 5, pp. 1891-921. 
Ueda, K., and B. Weder di Mauro, 2012, "Quantifying Structural Subsidy Values for Systemically Important Financial Institutions,” IMF Working Paper 12/128.

Vickers, J., 2010, “Central Banks and Competition Authorities: Institutional Comparisons and New Concerns," BIS Working Paper 331. 